\title{
G. LeBlanc Corporation, Relocating A Facility
}

Jonathan M. Furdek, Purdue University Calumet, USA

\begin{abstract}
This is a business case study describing a classical success story that brought a business from a store front music store to become the largest producer of brass and woodwind instruments in America. Additionally, the unique work environment and operating strategy of this firm was not only visionary, but enabled the company to prosper in a difficult labor market. Finally, the demise of the company when new management attempted to be a traditional company clearly indicates the important role of the entrepreneur. Although the focus of the case is on the decision to relocate a facility, this is an excellent case for courses in entrepreneurship, strategy, and operations.
\end{abstract}

Keywords: Entrepreneurship; Facility Location; Government and Business; Strategy

\section{CASE DESCRIPTION}

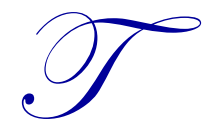

he primary focus of this case is on the analysis for a decision to locate a facility. The analysis is straightforward as students develop a model to compare three alternative sites and develop a strategy based on expected volume to identify the least cost alternative. However, the more interesting elements in the case is the background of the company and its owner and the elements that lead up to the final decision contained in the teaching notes. These two elements involve a true entrepreneurial success story as well as international business complications and unforeseen governmental regulations that influence the final decision.

\section{INTRODUCTION}

The loss from the fire was devastating. Not so much to production, but to the emotional tie and memories that Vito Pascucci, CEO of G. LeBlanc Corporation, had to those facilities in France. G. LeBlanc Corp. is the largest manufacturer of brass and woodwind musical instruments in America headquartered in Kenosha, Wisconsin. It is a private corporation and Vito Pascucci is the sole owner.

Vito reflected on the role that fate had played in his success. The fourth of five children to a working class family, Vito had worked with his brother Ben in the downtown storefront where Ben taught music lessons and Vito worked in the back repairing instruments. He had a knack for mechanical things which may explain the many patents he had obtained over the years in his business. It was during World War II when Vito met his country's call and was sent to Europe. He was slated to go to the front when Glenn Miller had him re-assigned to travel with his band as an instrument repairman. It was then that he befriended the LeBlanc family and he was in awe of the fine, high end wooden clarinets produced in the small factory outside of Paris. He dreamt of a time when he would return to his brother's store in Kenosha, Wisconsin and introduce these fine instruments to America.

After the war that is exactly what he did. But when the instruments arrived they needed to be broken down, tuned, and re-assembled before they could be sold. He needed more space and acquired a warehouse for his new enterprise. That warehouse, remodeled and modified numerous times, remains as the headquarters and principle manufacturing plant for G. LeBlanc. The business grew and Vito added several instruments to the line. He then added additional lines, buying out some of his competitors. Needing more space, he added facilities, acquiring the Holton plant and then building new facilities. 
The relationship with LeBlanc in Paris continued, when Leon LeBlanc, his life long friend and now in his senior years, came to Vito with a proposal to sell his interests to Vito. Vito purchased the French operations. But the French operations never did well, losing more than $\$ 1$ million per year. Vito considered closing some of the French operations and moving the unique key manufacturing operations to the United States. When he realized that there was no capacity in the existing facilities to house this operation, Vito asked his son, Leon, who was now the president of the corporation, to draw up plans for expansion. Leon came up with the following three proposals.

One alternative would be to maintain and upgrade the operations in Paris. Leon estimated that the annual cost to maintain a facility in France just to make keys would be $\$ 400,000$ with a variable cost of $\$ 200$ per set of keys. That cost included shipping, duties, handling, and inspection. The plant in South Kenosha was designed for expansion. Adding capacity at this plant would cost $\$ 500,000$ per year with a much improved variable cost of $\$ 133$ per set of keys. Another candidate was the headquarter facility. Although there was no existing space, Leon considered moving operations among existing plants. This would be expensive with an added annual cost of $\$ 600,000$ since a lot of parts and materials would need to be moved among the plants each year. But utilizing experienced employees brought about efficiencies and the variable cost was projected to be $\$ 100$ per set of keys.

Leon presented this information at the May board meeting along with the projection that this equipment could be utilized to produce keys on a number of high end clarinet models, including the Vito line. The projected volume would be around 3,000 sets of keys per year. Fate had brought Vito to another decision. What to do about the key operations and the French facilities. 


\section{TEACHING NOTES}

This case is appropriate for a one hour class session for undergraduate students in operations management attempting to develop a decision strategy for a capacity decision. There are three significant aspects of this case which suggest that it is also appropriate for a business strategy situation and for aspects of international business and government policy as well. These elements reside in the following teaching notes rather than in the body of the case.

One question would be "How did G. LeBlanc become the leader in its industry?"

Vito Pascucci created a culture in his facilities that could be described as paternalistic. He recognized that employees spent more awake hours at work than at home. So he sought to make the work environment as comfortable as home. His original facility, brought into production in the 1950's, had air conditioning and background music in the production plant. All areas were brightly lit and operations where employees would stand while working had cushioned mats. Areas that were intrinsically messy would have white Formica countertops so that they could be thoroughly cleaned at the end of the shift. While Vito was surrounded by capable professionals on his staff, the business was a family business with relatives in significant positions, implying a lifelong employment commitment. Competing for labor in a competitive labor environment, where the large employer was the automobile industry, Vito offered security. Although LeBlanc did not pay the wages of the auto industry, he never laid off employees for lack of work. He also employed a significant number of women and immigrants with a background in music. When there were issues in the plant, he would address them directly. He was an artist and kept the facilities and the grounds immaculate. Although his benefits package could not stand up to the benefits in the automobile industry, he would address issues on a case by case basis. For example, when he saw that one of his employees had a severe hair lip, he made arrangements for surgery at no cost to the employee, sending a message that he was compassionate and took care of his employees.

The second and more obvious question was to develop a strategy for selecting an alternative sight based on the cost information in the case. The students will utilize a cost-0volume model to analyze the alternatives. The costs for each alternative, where $\mathrm{X}$ is the quantity produced per year are:

(1) For the French facility $\mathrm{TC}_{1}=400,000+200 \mathrm{X}$

(2) To expand the south Kenosha facility $\mathrm{TC}_{2}=500,000+133 \mathrm{X}$

(3) To expand the headquarters facility TC $3=600,000+100 \mathrm{X}$

Students then can find the points where cost functions intersect at $X=1,500, X=2,000$ and $X=3,000$ sets of keys and develop a strategy based on cost. Below a demand of 1,500 sets, the restoration of the French site was least cost, for a demand between 1,500 and 2,000 sets, the plant in south Kenosha is preferred, and also for demand between 2,000 and 3,000 sets the south Kenosha plant is also least cost. For demand that exceeds 3,000 sets, the upgrade of the headquarters facility is preferred. These conclusions usually bring about a discussion regarding the accuracy of demand estimates and strategy.

The third question is "What did LeBlanc Do?"

There are many things you just cannot plan for. The firm decided to expand the south Kenosha plant as it was intended for expansion. However, in the process of developing plans, there was an unexpected turn of events. Apparently, the land was now considered a "wet land" and no development would be permitted. The firm did not even consider development of the French facility because of past experiences. It seems that the French facility is the longest continuing operation in Paris with a history dating back to the 1400's when it was a producer of corks for wine bottles, and this facility is now owned and operated by Americans. In addition to work rule issues and generous benefits, LeBlanc was required to have a senior officer on sight at least one week of every month, requiring LeBlanc to send over a senior person with regularity, which disrupted corporate operations. The plant was handed over to the French government. Reportedly, the plant was slated to become an insane asylum and at last report was occupied by homeless. This left the firm with one alternative. Vito Pascucci decided to expand for the future, adding 34,000 square feet to the plant and re-organizing the facility layout. When construction began, foundry sand was discovered on the site and had to be removed and sent to three separate disposal sites at a cost of nearly $\$ 500,000$. The expanded facility provided efficiency as well as flexibility and a new home for the key manufacturing. 


\section{AUTHOR INFORMATION}

Jonathan Furdek is a Professor of Operation Management at Purdue University Calumet. He is a graduate of Marquette University where he earned a Bachelor's degree in Mathematics and Economics, and a Master's degree in Economics. He earned a Ph.D. in Industrial Economics from the Krannert School of Management at Purdue University. His teaching and research interests are in operations management and business statistics. Specifically, his research expertise is in the long range impact consequences of investments in human capital and benefit incentives, specifically pension benefits. He and his wife, Linda, reside in Munster, Indiana. E-mail: furdek@purduecal.edu

\section{REFERENCES}

1. Bakke, N.A. and R. Hellburg. "The Challenges of Capacity Planning". International Journal of Production Economics (1993).

2. Hill, Terry. Manufacturing Strategy, $2^{\text {nd }}$ edition. McGraw-Hill Irwin. Burr Ridge, Illinois (1994).

3. Stevenson, William J. Operations Management, $10^{\text {th }}$ edition. McGraw-Hill Irwin. Burr Ridge, Illinois. (2009). 